\title{
Model Antrian Prioritas Pelayanan Perawatan Kesehatan Cerdas
}

\author{
A M H Pardede1 1 H Mawengkang², M Zarlis ${ }^{3}$, T Tulus 4 \\ 1Program Doktor Ilmu Komputer, Fakultas Ilmu Komputer, \\ Universitas Sumatera Utara, Medan, Indonesia \\ ${ }^{3}$ Fakultas Ilmu Komputer, Universitas Sumatera Utara, Medan, Indonesia \\ 2, 4 Fakultas Matematika, Universitas Sumatera Utara, Medan, Indonesia \\ akimmhp@live.com,m.zarlis@yahoo.com,hmawengkang@yahoo.com,tulus_jp@yahoo.com
}

\begin{abstract}
In realizing the success of a city into a smart city, it is necessary to improve services for people who are residents of the city, improving public services is a focus for stakeholders. Various efforts have been made, such as the construction of public service infrastructure and transportation infrastructure which has recently focused on intelligence. Providing health care services for people who need them quickly and on target is intelligent technology that can support the achievement of smart cities. In this study specifically discussed the provision of services to the community or patients who experience sudden health disorders or called emergency, in terms of managing emergency patients then given the main service (priority), so that the priority level of patient priorities can be divided into several priorities.
\end{abstract}

Keywords: Health Care, Patients, Priority, Queue.

\begin{abstract}
Abstrak-Dalam mewujudkan keberhasilan suatu kota menjadi kota yang cerdas diperlukan peningkatan pelayanan bagi masyarakat yang menjadi penduduk pada kota tersebut, peningkatan pelayanan umum menjadi fokus bagi para pemangku kepentingan. Berbagai upaya dilakukan, seperti pembangunan infrastruktur pelayanan umum dan infrastruktur trasnportasi yang akhir-akhir ini berfokus pada kecerdasan. Pemberian pelayanan perawatan kesehatan bagi masyarakat yang membutuhkannya secara cepat dan tepat sasaran adalah merupakan teknologi cerdas yang dapat mendukung tercapainya kota cerdas. Pada peelitian ini khusus dibahas mengenai pemberian pelayanan bagi masyarakat atau pasien yang mengalami ganguan kesehatan secara mendadak atau disebut darurat, dalam hal menagani pasien darurat maka diberikan pelayanan utama (prioritas), sehingga tingkat kepentingan prioritas pasien dapat dibagi menjadi beberapa prioritas.
\end{abstract}

Kata kunci: Perawatan Kesehatan, Pasien, Prioritas, Antrian.

\section{PENDAHULUAN}

Smart City adalah abstraksi terbesar di antara nama-nama yang digunakan, meskipun beberapa bagian kota hanya menggunakan sistem pemantauan negara kota. Smart City adalah sebuah konsep dan masih belum ada definisi konsep yang jelas dan konsisten di antara akademisi dan praktisi. Dalam penjelasan sederhana, kota pintar adalah tempat di mana jaringan dan layanan tradisional dibuat lebih fleksibel, efisien, cerdas, dan berkelanjutan dengan penggunaan teknologi informasi, digital dan telekomunikasi, untuk meningkatkan operasi demi kepentingan penduduk. Dengan kata lain, di kota yang cerdas, teknologi digital diterjemahkan menjadi layanan publik yang lebih baik bagi penduduk, dan untuk 
penggunaan sumber daya yang lebih baik sambil berdampak pada lingkungan yang kurang menguntungkan [1].

Konsep kota cerdas adalah untuk memudahkan masyarakatnya dalam mendapatkan informasi secara cepat dan tepat. Adapun 6 aspek smart city diantaranya: Smart Governance, Smart People, Smart Living, Smart Mobility, Smart Economy, dan Smart Environment [2]. Perkembangan Internet of Things (IoT) menjadi paradigma komunikasi yang begitu pesat, di mana hampir semua objek dalam kehidupan sehari-hari akan dilengkapi dengan mikrokontroler, transceiver untuk komunikasi digital, dan tumpukan protokol yang sesuai untuk dapat berkomunikasi satu sama lain. Pengguna IoT menjadi bagian integral dari Internet [3]. Konsep IoT bertujuan untuk membuat penyebaran informasi melalui Internet lebih merata penyebarannya. Selain itu, dengan memungkinkan akses dan interaksi yang mudah dengan berbagai perangkat-perangkat cerdas, seperti peralatan rumah tangga, kamera pengawas, sensor pemantauan, aktuator, kendaraan, dan sebagainya. IoT akan mendorong pengembangan sejumlah aplikasi yang memanfaatkan jumlah dan variasi data yang sangat besar yang dihasilkan oleh objek-objek tersebut untuk memberikan layanan baru kepada warga, perusahaan, dan administrasi publik. Paradigma ini memang menemukan aplikasi di banyak bidang yang berbeda, seperti otomatisasi rumah, otomatisasi industri, bantuan medis, perawatan kesehatan keliling, bantuan orang tua, manajemen energi cerdas dan jaringan cerdas, otomotif, manajemen lalu lintas, dan banyak lainnya[4].

\section{METODOLOGI PENELITIAN}

Komponen kota pintar adalah: infrastruktur pintar, rumah pintar, bangunan pintar, transportasi pintar, energi pintar, perawatan kesehatan pintar, teknologi pintar, tata kelola cerdas, pendidikan cerdas, dan warga cerdas. Kota pintar yang berbeda memiliki tingkat komponen kecerdasan yang berbeda, tergantung pada fokus kota pintar mereka. Berbagai atribut kota pintar meliputi keberlanjutan, kualitas hidup (Quality of Life / QoL), urbanisasi, dan kecerdasan. Keberlanjutan kota yang cerdas terkait dengan infrastruktur dan pemerintahan kota, energi dan perubahan iklim, polusi dan limbah, dan masalah sosial, ekonomi dan kesehatan. Kualitas Hidup (QoL) dapat diukur dari segi kesejahteraan emosional dan finansial warga. Aspek urbanisasi kota pintar mencakup banyak aspek dan indikator, seperti teknologi, infrastruktur kota, pemerintah, dan ekonomi. Keunikan kota yang cerdas dikonseptualisasikan sebagai ambisi untuk meningkatkan standar ekonomi, sosial dan lingkungan kota dan penduduknya. Aspek-aspek kecerdasan kota yang paling sering dikutip meliputi ekonomi cerdas, orang pintar, tata kelola cerdas, mobilitas cerdas, dan kehidupan cerdas [1].

Kebutuhan akan tercapainya kota cerdas ini berasal dari interkoneksi sinergis sector industri dan layanan utama, seperti smart health care, smart governance, smart mobility, smart utility, smart building, dan smart environment. Sektor-sektor ini juga telah dipertimbangkan dalam proyek kota cerdas untuk menentukan kriteria peringkat yang dapat digunakan untuk menilai tingkat "kecerdasan" kota-kota. Meskipun demikian, pengembangan Kota cerdas 
terkadang terhambat karena sering berbenturan dengan kepentingan politik, teknis, dan keuangan [5]. Situasi perekonomian yang buruk dapat menghambat pengembangan Kota cerdas, tetapi ada upaya jalan keluar yang dapat dilakukan, yaitu dengan mengembangkan layanan-layanan fasilitas umum, seperti pelayanan perawatan kesehatan yang cerdas, parkir cerdas dan bangunan pintar [5].

Di berbagai tempat, terutama pedesaan pelayanan perawatan kesehatan tidak memadai, demikian juga dengan sumber daya yang terbatas yang berbanding terbalik dengan meningkatnya permintaan pelayanan perawatan kesehatan, Dalam menangani masalah inilah dibutuhkan pemberian pelayanan perawatan kesehatan yang pintar. Perawatan kesehatan pintar dapat dikonseptualisasikan sebagai kombinasi entitas termasuk perawatan kesehatan tradisional, biosensor cerdas, perangkat yang dapat digunakan, teknologi informasi dan komunikasi (TIK), dan sistem ambulans cerdas. Ide layanan kesehatan pintar disajikan pada Gambar 1. Gagasan tentang perawatan kesehatan pintar, menjelaskan berbagai komponen perawatan kesehatan pintar termasuk sensor tubuh yang ada, rumah sakit pintar, dan respon darurat cerdas.

Pada rumah sakit pintar, berbagai mekanisme termasuk TIK, komputasi awan, aplikasi ponsel pintar, dan teknik analisis data canggih, digunakan untuk operasi mereka. Data pasien dapat dilakukan secara real-time di berbagai kantor di rumah sakit pintar atau bahkan rumah sakit pintar di berbagai kota. Teknisi medis, perawat, dan dokter dapat memiliki akses untuk menguji data tanpa kehilangan waktu dalam mentransfer informasi yang sama secara fisik dari satu kantor ke kantor lainnya. Demikian pula, dokter yang berbeda dapat melihat informasi untuk menilai kondisi pasien. Jadi keputusan real-time tentang kondisi kesehatan pasien dan perawatan yang tepat dapat dilakukan [1].

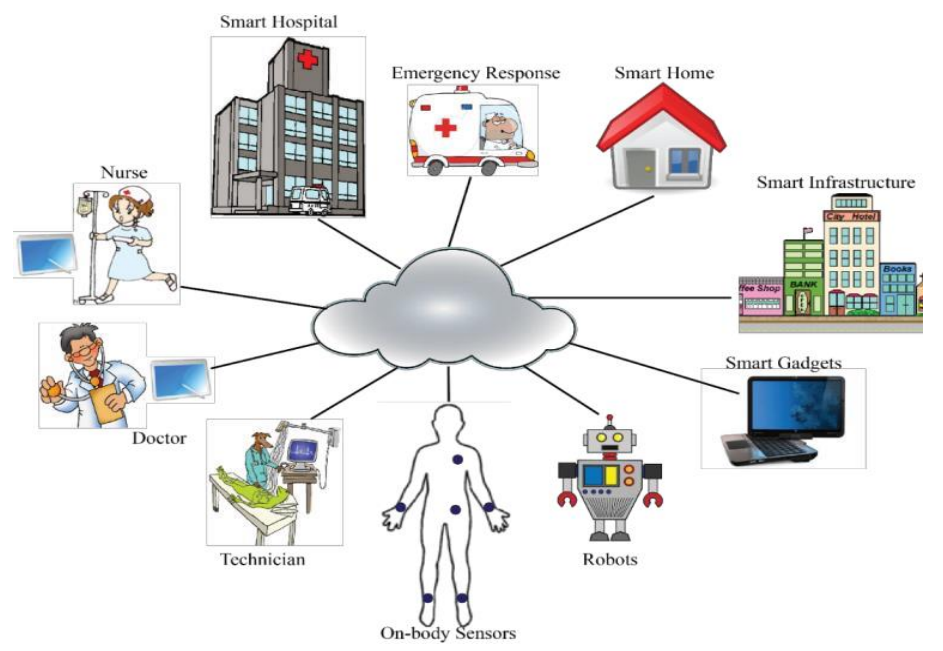

Gambar 1. Gagasan tentang perawatan kesehatan yang cerdas.

Perawatan Kesehatan Cerdas yang efektif membutuhkan kolaborasi di antara banyak orang dan sumber daya, termasuk pasien, dokter, dan profesional perawatan kesehatan, serta bagian manajemen pengelolaan fasilitas rumah sakit [6]. Kolaborasi ini sangat penting untuk pengaturan perawatan kesehatan di 
rumah, di mana anggota keluarga pasien juga dapat terlibat dalam hal pasien tidak lagi dapat bertindak. Efektivitas kolaborasi, pada gilirannya, tergantung pada komunikasi dan informasi di antara orang yang berbeda dalam pengaturan ini [7]. Buruknya efisiensi dalam komunikasi dokter dan perawat dengan pasien dan ketidakmampuan untuk memantau kesehatan pasien di rumah adalah faktor utama yang berkontribusi.

Sistem Smart Heath dapat memfasilitasi manajemen kesehatan masyarakat. Kebijakan dan keputusan dapat dipersonalisasi (sesuai kebutuhan) untuk setiap kota dan bahkan kabupaten, berdasarkan data dari populasi, kesehatan, lingkungan, iklim, fasilitas yang tersedia, dan infrastruktur yang ada. Peluang yang timbul dari penambangan data dapat mengoptimalkan pengambilan keputusan kesehatan masyarakat tanpa batas [8].

Dengan menganalisis apa yang telah dilakukan oleh peneliti dan pengembang, semua tujuan utamanya adalah bagaimana mendapatkan informasi tentang kondisi kesehatan pengguna perangkat, dalam hal ini harus mempertimbangkan bagaimana layanan pengguna perangkat jika mengalami masalah kesehatan, dan tindakan apa yang perangkat pintar harus dilakukan atau tindakan dokter sebagai pengambil keputusan manajemen. Tindakan perangkat cerdas atau perangkat pintar yang digunakan memerlukan model sistem pendukung keputusan untuk perawatan kesehatan pintar yang dapat menangani tindakan yang akan dilakukan, dengan menyinkronkan data input yang diterima dari lebih dari satu perangkat pintar yang digunakan, di mana percobaan ini berupaya mengajukan suatu keputusan model pendukung yang menerima input model antrian dari data yang diperoleh dari pasien atau dari perangkat yang digunakan oleh pasien, sehingga dapat diberikan keputusan tindakan apa yang akan dilakukan oleh pasien (dalam hal ini dapat dikatakan bahwa ada di pasien lokasi atau keluarga pasien) dan tindakan apa yang akan dilakukan oleh pelayan (dalam hal ini adalah bagian manajemen rumah sakit).

\section{METODOLOGI PENELITIAN}

Dalam perawatan kesehatan adalah model antrian dengan tipe pasien yang berbeda, di mana satu atau lebih jenis pasien memiliki prioritas di atas jenis lain. Adalah lebih tepat untuk mempertimbangkan model M / G / 1 antrian dengan tipe pasien. Prioritas tipe 1 pasien adalah penangan prioritas tertinggi, prioritas tipe 2 pelanggan adalah pelanggan prioritas tertinggi kedua dan seterusnya [9].

Layanan gawat darurat pada rumah sakit telah berkembang selama bertahun-tahun, khususnya dengan pengenalan dan evolusi sistem triase [10] dengan memprioritaskan pasien berdasarkan tingkat urgensinya. Salah satu yang paling luas metode triase yang digunakan adalah sistem Manchester [11], [12]. Dalam sisem triase pasien diklasifikasikan menjadi lima kelompok sesuai dengan tingkat urgensinya [13]. 


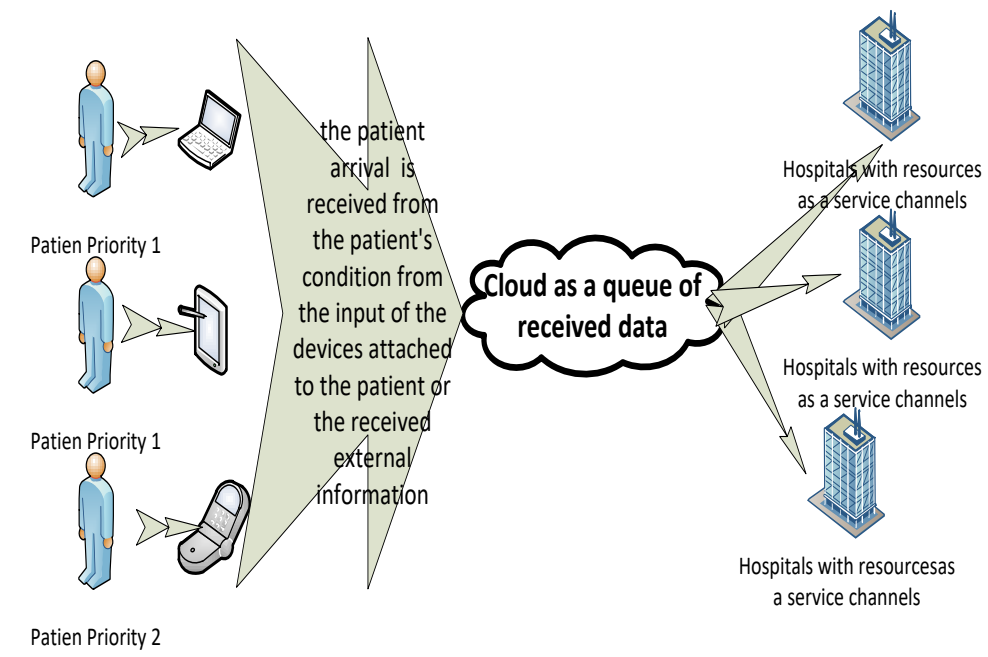

Gambar 2. Model Antrian Prioritas Pelayanan Perawatan Kesehatan

Hasil dari rancangan dari model ini akan memberikan system pendukung keputusan yang lebih baik dalam penanganan masalah medis pada pasien, sehingga pasien cepat mendapatakan pertolongan pertama dan tindakan apa saja yang akan dilakukan. Pada Gambar 3. Desain model sistem pendukung keputusan untuk perawatan kesehatan yang cerdas menggambarkan model sistem pendukung keputusan untuk perawatan kesehatan pintar dimulai dengan input data pasien atau data yang diterima dari perangkat yang dipasang pasien atau yang disebut perangkat pintar yang melekat pada pasien. data akan diterima oleh server yang menangani distribusi pelayanan pasien, jika pasien merupakan prioritas 1 / utama yang dalam hal ini telah dibersihkan pada bagian sebelumnya maka pasien harus segera dilayani dan di prioritaskan di rumah sakit terdekat yang terhubung. ke sistem server, dan pada kondisi ini juga diusulkan untuk segera mengambil pasien, dan mungkin pasien dapat dikawal oleh keluarga pasien atau orang terdekat juga didorong, karena dalam hal ini prioritas pertama adalah mengambil pertolongan pertama kepada pasien. Selanjutnya, distribusi perawatan pasien yang merupakan prioritas 2 akan diberikan oleh layanan rumah sakit tergantung pada keputusan yang akan diberikan oleh sistem, di mana pertimbangan dalam penilaian adalah ketersediaan sumber daya di rumah sakit, ketersediaan dokter spesialis yang menangani penyakit atau ketersediaan poliklinik, ketersediaan peralatan pendukung yang dibutuhkan dan ketersediaan kamar rawat inap yang memberikan informasi tentang jenis / kelas ruangan. Berikut ini disajikan kerangka kerja Desain model sistem pendukung keputusan untuk perawatan kesehatan pintar[14]. 


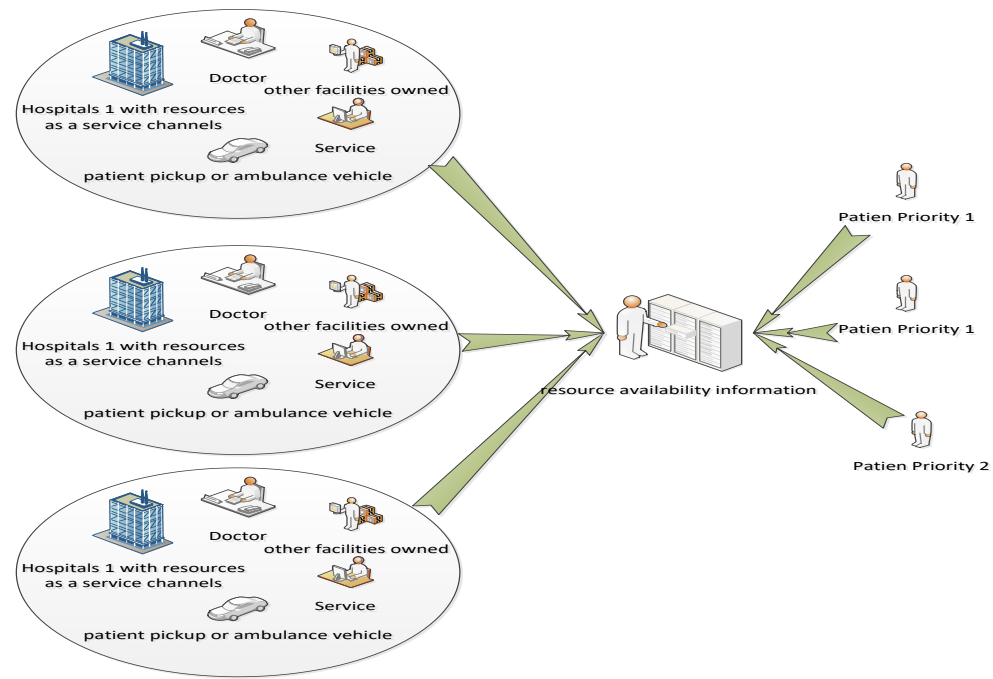

Gambar 3. Desain model sistem pendukung keputusan untuk perawatan kesehatan yang cerdas

\section{KESIMPULAN}

Untuk mendapatkan hasil dari model yang digunakan untuk smart health sesuai dengan masalah dan tujuan yang ingin dicapai, berikut ini menggambarkan kerangka penelitian sebagai tahap dalam pelaksanaan penelitian dari awal hingga pencapaian hasil akhir. Penelitian ini dibagi menjadi beberapa tahap:

a. Buat model antrian dalam layanan kesehatan masyarakat.

b. Membuat model matematik berdasarkan nilai fungsi tujuan yang diharapkan.

c. Memberikan asumsi-asumsi awal atau keterbatasan terhadap sumberdaya

d. Membuat model sebagai Keputusan dalam layanan kesehatan masyarakat.

e. Gabungkan kedua model untuk mendapatkan model Smart HealthCare.

f. Melakukan simulasi sebagai pengujian

\section{DAFTAR PUSTAKA}

[1] S. P. Mohanty, U. Choppali, and E. Kougianos, "Everything you wanted to know about smart cities," IEEE Consum. Electron. Mag., vol. 5, no. 3, pp. 60-70, 2016.

[2] F. Casino, C. Patsakis, E. Batista, O. Postolache, A. Martínez-Ballesté, and A. Solanas, "Smart Healthcare in the IoT Era: A Context-Aware Recommendation Example," in 2018 International Symposium in Sensing and Instrumentation in IoT Era, ISSI 2018, 2018.

[3] S. M. Riazul Islam, Daehan Kwak, M. Humaun Kabir, M. Hossain, and Kyung-Sup Kwak, "The Internet of Things for Health Care: A Comprehensive Survey," IEEE Access, vol. 3, pp. 678708, 2015.

[4] B. P., C. G., C. A., and F. L., "Convergence of MANET and WSN in IoT urban scenarios," IEEE Sens. J., 2013.

[5] N. Walravens and P. Ballon, "Platform business models for smart cities: From control and value to governance and public value," IEEE Commun. Mag., 2013.

[6] A. Alaiad and L. Zhou, "Patients' adoption of WSN-Based smart home healthcare systems: An integrated model of facilitators and barriers," IEEE Trans. Prof. Commun., vol. 60, no. 1, pp. 4-23, 2017.

[7] L. Lapointe, J. Ramaprasad, and I. Vedel, "Collaborating through social media to create health awareness," in Proceedings of the Annual Hawaii International Conference on System Sciences, 2013, pp. 792-801. 
[8] A. Solanas et al., "Smart health: A context-aware health paradigm within smart cities," IEEE Commun. Mag., vol. 52, no. 8, pp. 74-81, 2014.

[9] I. Adan and J. Resing, "Queueing Theory," Technology, vol. 15, no. x, p. 180, 2002.

[10] I. R. S. Robertson-Steel, "Evolution of triage systems," Emergency Medicine Journal. 2006.

[11] W. S. Pérez, M. Gómez Muñoz, E. Bragulat, and A. Álvarez, "Triage: A key tool in emergency care," An. Sist. Sanit. Navar., 2010.

[12] M. Christ, F. Grossmann, D. Winter, R. Bingisser, and E. Platz, "Modern triage in the emergency department.," Dtsch. Arztebl. Int., 2010.

[13] B. Lima and J. P. Faria, "Towards real-time patient prioritization in hospital emergency services," in 2018 IEEE 20th International Conference on e-Health Networking, Applications and Services, Healthcom 2018, 2018.

[14] A. M. H. Pardede et al., "Framework For Patient Service Queue System For Decision Support System on Smart Health Care," Int. J. Eng. Technol., vol. 7, no. 2.13, pp. 337-340, 2018. 